\title{
Book Review: Mixed Communities: Gentrification by Stealth?
}

\author{
by blog admin
}

\section{December 18, 2012}

Encouraging neighbourhood social mix has been a major goal of urban policy and planning in a number of different countries. This book draws together a range of case studies by international experts to assess the impacts of social mix policies and the degree to which they might represent gentrification by stealth. Andrew Molloy thinks after fifty years of botched urban policies, the case studies featured in this book might provide a window of understanding into the full ramifications of urban social mix policies.

\section{Mixed Communities - Gentrification by Stealth? Gary Bridge, Tim Butler and Loretta Lees (eds.). Policy Press. October 2012.}

The idea of 'social mix' has been at the forefront of urban theorising since Jane Jacob's seminal book The Death and Life of Great American Cities was published in 1961. Interestingly, this book came around the same time the word 'gentrification' was first introduced to urban theory by sociologist Ruth Glass. Since then, the two terms have been deployed by a wide range of actors in the public realm for apparently divergent purposes. The volume Mixed Communities - Gentrification by Stealth? explores the use of these terms and the possibility of their connectedness.

Edited by Gary Bridge, Tim Butler and Loretta Lees, this collection of academic articles and case studies has an impressive lineage. Anyone with a cursory awareness of urban renewal and social change research will undoubtedly have encountered the writings of one, if not all, of its highly regarded editors.

In his chapter 'Social Mix and Urban Policy' Patrick Le Gales discusses gentrification and social mix from the European perspective and suggests that the use of the terms differs significantly from one country to the next, often with political motivations. Le Gales proffers that in increasingly difficult times for inner-city urban areas, the goals of social policy are increasingly difficult to achieve satisfactorily. Policymakers therefore choose intentionally vague language so they are able to claim any positives and shift the blame for any negatives. "Social mix policy," proposes Le Gales, "is a very good example of this." Le Gales goes on, however, to recommend that social policy is a key tool in urban social policy, despite the vagaries.

The most fascinating aspect of this volume are the specific case studies which show the uneasy link between gentrification and social mix policies. In his chapter 'Social Mixing and the Historical Geography of Gentrification' David Ley describes two starkly different examples located in inner-city Vancouver. "False Creek" is discussed as a social mix success story, featuring "a series of juxtaposed enclaves... [each] varying socially from those adjacent to it," a strategy never voiced by the planners and never raised by its largely contented populace. This is compared with "Downtown Eastside," an area considered ripe for urban renewal due to it's history of blight and depravation, and as with most contemporary regeneration projects achieving social mix was considered integral. Local advocacy groups came forward in opposition to this policy, highlighting the existing diversity of the district in terms of age, gender, employment status, ethnicity, sexuality, disability and lif estyle. "While the position of the advocates might be criticised as promoting 
segregation," Ley expounds, "this is only true if the category in question is social class." These case studies are enlightening; the two diverse examples serving as great examples of the potential pitfalls of 'social mix' policy. Indeed, the 'success' story of False Creek seems only accidentally successful, whereas the case of Downtown Eastside shows a neighbourhood thriving due to a concerted effort on behalf of incumbent residents.

In their chapter "Social Mix as the Aim of a Controlled Gentrification Process" Marie-Helene Bacque and Yankel Fijalkow take us through the complex applications of social mix policy and attitudes to gentrification (embourgoisement) in Paris since the early 1970s, focussing in on the area of Goutte d'Or. The writers' description of the area prior to it's regeneration are of a largely working class population, made up primarily of immigrants. Despite poor housing conditions it was considered an important commercial centre particularly for exotic produce. It is very striking then that the proposed slum clearance also featured a strong policy for social mixing, despite the apparently positive state of social conditions in the area. The piece goes on to describe how the areas 'new' residents, largely French middle class professionals, began to consolidate their position by challenging the very policy that enabled their residence. Their original decision to move to the area was based on low property prices which eventually rose as the demographics of the area changed. Thus the residents actively challenged anything with the potential to lower prices, such as the bolstering of the working class or immigrant population, for reasons of more favourable property investment. As they were mostly professionals, they possess the social and political power to win many of these arguments which serves as a fascinating socio-urban paradox and a prime example of one of the key pitfalls in implementing such a policy. This case study illustrates perfectly the ease at which social mix policy can shift to become one of gentrification.

Reading through this collection one gets a pervading sense of the ill-defined and unstructured nature of social mix policy. From the well-meaning liberals of the 1960s to neo-liberal social concern in the contemporary city, 'social mix' has been touted as the catch-all solution for inner-urban poverty and dilapidation. What these case studies expose is the absent-minded nature of applying 'social-mix' as a broad brush policy. While it seems like a worthwhile aim, the objectives in achieving this aim needs to be far more nuanced and contextually sensitive. It also needs to be saf eguarded against market forces which drive up property prices and the 'have-our-cake-and-eat-it' attitudes of the middle classes, who want the appearance of social mix but very much on their own terms.

This volume is extremely useful for anyone hoping to get to grips with the complex and little-understood issues regarding social mix policy and gentrification. As noted in the book's afterword, the divergent attitudes and applications to social mix evidenced throughout this collection "are largely ineffective in enhancing the welf are of the [poor], and in some cases detrimental to the welfare of the urban poor." This highlights the current lack of rigorous academic thinking in the urban sociology which drives policy in innercity areas. These decisions have a profound affect on the life of a city and it's denizens, we therefore owe it to ourselves to fully understand their ramifications. With fifty years of botched urban policies behind us, it seems these case studies hold the key to this type of understanding.

Andrew Molloy is an architectural PhD student based at the University of Ulster, Belf ast Northern Ireland. His research centres upon trying to create a theoretical cross-disciplinary platform based on recent paradigm shifts taking place within philosophy, sociology and neuroscience. Using urban design in Belfast as a case study, Andrew hopes to critique the numerous large scale planning decisions which have def ined the contemporary city and postulate a way forward. Andrew is a frequent contributor to the PLACE blog, the architecture and built environment centre for Northern Ireland, as well as writing for RSUA Perspective magazine and arts newspaper 'The Ulster Folk.' Read reviews by Andrew.

Related posts:

1. Book Review: New Urbanism: Life, Work and Space in the New Downtown (6.8)

2. Book Review: When War Ends: Building Peace in Divided Communities (6.6) 
3. Book Review: The Transatlantic Collapse of Urban Renewal: Postwar urbanism from New York to Berlin (6.6)

4. Book Review: The Triumph of the City (6.1)

5. New York, London, Paris, Munich: Living in the endless city (6) 